DOI: $10.15290 /$ bsl.2021.18.03

\title{
Maciej Dajnowski
}

Wydział Filologiczny

Uniwersytet Gdański

e-mail: mdajnowski@wp.pl

ORCID: 0000-0003-4774-3293

\section{Lebensraum i przestrzeń abjectu. O Białym kamieniu Anny Boleckiej}

Jedną z przesłanek do napisania niniejszego artykułu jest moje prywatne doświadczenie odbioru dwóch tekstów kulturowych - doświadczenie obarczone trudnym do określenia doznaniem, zawieszonym pomiędzy niemym, "zatykającym”, afektem a trudną do zdefiniowania emocją ${ }^{1}$. Zarówno Bękarty wojny Quentina Tarantino ${ }^{2}$, jak i Noc żywych Żydów Igora Ostachowicza ${ }^{3}$ uwiodły mnie swego czasu czarnym humorem, postmodernistyczną zręcznością w komponowaniu patchworkowych całości z używanych "resztek po" [resp. recycling, bricolage], lekkością makabreski ${ }^{4}$. Te odczucia obciążone są jednak aurą „złego sumienia” - towarzyszy im niezdefiniowany niepokój co do mego prawa do śmiechu. Zachowując wszelkie proporcje - doświadczam wobec nich rozdarcia nieco zbliżonego do konfliktu opisanego przez

1 Rozróżniam, rzecz jasna w duchu zrodzonym w ramach zwrotu afektywnego [por. np. R. Nycz, Afektywne manifesty, „Teksty Drugie” 2014, nr 1].

2 Inglorious Basterds (Bękarty wojny), scen. i reż. Q. Tarantino, Universal Pictures 2009.

3 I. Ostachowicz, Noc żywych Żydów, Warszawa 2012.

4 Mam tu na myśli koncepcję makabreski jako kategorii estetycznej zdefiniowanej przez „lekkość” w serwowaniu makabry (okrucieństwa, okropieństwa, obrzydliwości), dialektycznie rozpiętej między biegunami przerażenia czy odrazy i śmiechu. Szczegółowo opisuje to Brygida Pawłowska-Jądrzyk w: Sens i chaos w grotesce literackiej. Od "Pałuby" do „Kosmosu”, Kraków 2002, oraz w: Ciężar i lekkość w kulturze. Poetyka, estetyka, style myślenia, Warszawa 2017. 
Georges'a Didi-Hubermana w Obrazach mimo wszystko ${ }^{5}$. Coś wewnątrz mnie hołduje przekonaniu nie tyle może o nieprzedstawialności Holocaustu, ile o jego zasadniczo odrębnym charakterze ontycznym, który stoi na przeszkodzie traktowaniu (uświęconych) obrazów Zagłady jako swobodnych signifikantów, żetonów w bricoleurskim przedsięwzięciu generowania nowych, zaktualizowanych dla potrzeb momentu historycznego znaczen, w wolnej grze znaczących, nawet jeżeli jest to gra o sumie niezerowej, to znaczy w jakimś sensie ubogacająca mój obraz świata ${ }^{6}$. Innymi słowy - zarówno oglądanie filmu twórcy Pulp fiction, jak i obcowanie z powieścią Ostachowicza, łączą się $\mathrm{w}$ moim przypadku z kwestionowaniem prawa do śmiechu, do lekkości odbioru, która nie daje się uzgodnić z doświadczeniem Numinosum właściwym (także w znaczeniu wiążącego mnie Prawa) stawaniu twarzą w twarz $\mathrm{z}$ reprezentacjami Zagłady.

Pewne tropy $\mathrm{ku}$ zrozumieniu tego specyficznego rozdarcia odnajduję w dość już klasycznych dzisiaj koncepcjach groteski (ujętej jako kategoria estetyczna) - jej koligacjach ze śmiechem i makabreską ${ }^{7}$ oraz $\mathrm{w}$ dobrze $\mathrm{w}$ polskim dyskursie naukowym zadomowionej teorii Lee Byrona Jenningsa, która reakcję na groteskowość obrazu przemieszcza na poziom nieuświadomionego odzewu na sugestię zagrożenia integralności kruchego, ludzkiego istnienia ${ }^{8}$. Jest to reakcja bipolarna, niepodlegająca ujęciu racjonalnemu, zdialektyzowaniu. Przerażenie i trzewiowy, przedrefleksyjny śmiech nie dysponują żadnym tertium comparationis, nie patronuje im żadne heglowskie trzecie, syntezujące oba sprzeczne doświadczenia w coś, co wpisze się w logos mojego

5 G. Didi-Huberman, Obrazy mimo wszystko, przeł. M. Kubiak Ho-Chi, Kraków 2008. W eseju tym Didi-Huberman opisuje wzburzenie, do jakiego doprowadziło ujawnienie istnienia kilku kadrów fotograficznych dokumentujących palenie zwłok w Birkenau. Do chwili ich odnalezienia i opublikowania brak wizualnych dokumentów tej zbrodni pozostawał w zgodzie z etycznym źródłowo przekonaniem o fundamentalnej nieprzedstawialności Holocaustu. Fakt istnienia materialnych świadectw zbrodni zdawał się niektórym odbiorcom czymś głęboko obrazoburczym. Nałożyło się tu utożsamienie idei etycznej („,koszmar Shoah jest nie do pomyślenia”), przekonania o nieadekwatności dyskursów zastanych dla jego przedstawienia (,,Shoah nie da się opowiedzieć, przedstawić w słowie") z retorsją skierowaną przeciwko fotografii rozumianej jako przedstawienie tout court. W efekcie kwestionowano nie tylko moralny wymiar publikacji zdjęć z Birkenau, ale dla podtrzymania tego gniewnego afektu posuwano się wręcz do kwestionowania ich prawdziwości, a nawet samej możliwości ich zaistnienia.

6 Por. w tym kontekście np. rozważania o obcości i przyswojeniu charakterystyczne dla refleksji hermeneutów; np. P. Ricoeur, Język, tekst, interpretacja, wyb. K. Rosner, przeł. K. Rosner, P. Graff, Warszawa 1997, s. 165.

7 Por. B. Pawłowska-Jądrzyk, Sens i chaos w grotesce literackiej. Od "Pałuby" do "Kosmosu” i Ciężar i lekkość w kulturze. Poetyka, estetyka, style myślenia.

8 Por. L.-B. Jennings, Termin "groteska", przeł. M.B. Fedewicz, „Pamiętnik Literacki” 1979, z. 4 . 
doświadczenia lub w Logos świata. Są diametralnie odrębne - przerażenie jest odpowiedzią na spojrzenie w otchłań, śmiech - częściowo katharktyczną zasłoną, na już-poddanym-refleksji poziomie bliską odczuciu Absurdu, swoistym narzędziem homeostazy, umożliwiającej jakieś funkcjonowanie mimo świadomości balansowania na granicy nieistnienia.

To, co pisze Jennings, nie satysfakcjonuje mnie w stopniu wystarczającym. Poetyka groteski czy absurdu odniesiona do tematu Holocaustu ( $\mathrm{Nu}$ minosum!) zdaje się pełnić funkcję instrumentalną - łagodzenia naszego lęku przed byciem-w-świecie. Numinalność Zagłady (przyjmowana tu w sensie świeckim - wyróżnionego, unikatowego, zdarzenia w historii piśmiennego Zachodu/ludzkości lub transgresji humanistycznego złudzenia w skali fundującej nową , jakość"), wyklucza posługiwanie się jego obrazami w ogólnym celu łagodzenia mdłości właściwych rozszczepionemu podmiotowi naszych czasów.

Dawne koncepcje doświadczenia groteskowego/doświadczenia Absurdu zdają się przy tym pomijać jeszcze jeden, wstydliwy, aspekt recepcji obrazów traumatyzujących - źle skrywaną satysfakcję, fascynację ${ }^{9}$, rozkosz płynącą z podglądania okrucieństwa i transpasywnego w nim uczestnictwa. Jako że temat ściśle wiąże się z polskim uwikłaniem afektywnym w doświadczenie Holocaustu, przywołam wzmiankowaną kategorię w istotnym dla mnie ujęciu Andrzeja Ledera. Teoria transpasywności mówi, zatem, że

pewne działania i przeżycia Innego mogą być doświadczane jak własne, generując stany emocjonalne, zwykle przypisywane własnej aktywności. Na tym polega, wspomniana już, formuła Slavoja Žižka: „gdy inny się raduje, ja raduję się wraz z nim. [...] moje najbardziej intymne uczucia mogą ulec radykalnemu uzewnętrznieniu, dosłownie mogę się "śmiać i płakać za pośrednictwem innego»". Doświadczeniu temu jednocześnie towarzyszy swoiste poczucie pasywności. To połączenie doświadczania emocji - przede wszystkim rozkoszy i strachu - oraz pasywności przypomina sytuację podmiotu we śnie. Wszystko dzieje się, ale jakby "samo”, poza podmiotową władzą, która polega na poczuciu sprawstwa swoich czynów, a które nazywa się „wolą" ${ }^{10}$.

$*$

9 Por. fascinatio Pascala Quignarda w P. Quignard, Seks i trwoga, przeł. K. Rutkowski, Warszawa 2002.

10 A. Leder, Prześniona rewolucja. Ćwiczenia z logiki historycznej, Warszawa 2014, s. 21; cytowany przez autora fragment eseju Žižka: S. Žižek, Przekleństwo fantazji, przeł. A. Chmielewski, Wrocław 2001, s. 169. 
Wszystko, co zostało tu do tej pory napisane, służy przybliżeniu przyjętej przeze mnie $\mathrm{w}$ niniejszym artykule pozycji - nie tyle hermeneutycznej może, ile - afektywnej: do interpretacji przystępuję bowiem jako człowiek przejęty (przynajmniej chwilami) poczuciem osobistej odpowiedzialności za Holocaust... Bez znaczenia jest tu fałszywy - retroaktywny i fantazmatyczny - charakter tej odpowiedzialności, wagę zachowuje moc afektu wyobraźni zdominowująca wszystkie dalsze, z pozoru tylko dążące do obiektywizmu odczytania, procedury interpretacyjne.

Odkładam więc na inną okazję Tarantino i książkę Ostachowicza. A może nie tyle odkładam, ile biorę oba te teksty kultury $\mathrm{w}$ rodzaj nawiasu, przekonany, że uda mi się do źródeł afektualnych zawirowań dotrzeć inną drogą, tylko z pozoru okrężną. W tym celu przyjrzę się innej współczesnej powieści, w której Zagłada występuje jedynie na prawach pobocznego motywu w konstrukcji tła i ustanawia pewien horyzont historyczny, mitologiczny i poetycki odpominanych w narracji zdarzeń; chodzi tu o Biały kamień Anny Boleckiej ${ }^{11}$.

Choć literackie świadectwo o Żydach i Holocauście nie wydaje się pierwszoplanowym zadaniem, jakie postawiła sobie autorka powieści, nie ulega równocześnie wątpliwości, że utwór wpisuje się w bogatą konstelację tekstów ustanawiających $\mathrm{w}$ naszej kulturze tematyczno-pojetyczny system reprezentacji „Żydzi polscy, polscy goje, Zagłada”. Dla wciąż przyrastającego korpusu piśmiennictwa (także beletrystycznego) tego rodzaju, zewnętrzną, historycznoliteracką cezurą jest oczywiście rok 2000, moment opublikowania Sąsiadów Jana Tomasza Grossa (po którym nastąpiły jeszcze reportaż Anny Bikont (2004-2012) i dramat Tadeusza Słobodzianka (2008)) ${ }^{12}$. Skandal Jedwabnego zamyka symbolicznie epokę „bukolicznego" mitu (właściwego choćby literaturze małych ojczyzn), w którym Zagłada jest obecna, ale swym ostrym cieniem odgranicza bezpieczną przestrzeń mitu wielokulturowości i wzajemnego poszanowania, pozostając domeną siły obcej, której działanie

\footnotetext{
11 A. Bolecka, Biały kamień, Warszawa 1994.

12 T. Gross, Sasiedzi. Historia zagłady żydowskiego miasteczka, Sejny 2000; A. Bikont, My z Jedwabnego, Warszawa 2004 i rozszerzone wydanie Warszawa 2012; T. Słobodzianek, Nasza klasa [premiera 2008], Gdańsk 2009. Pozycje te umownie wyznaczają pewien moment zmiany paradygmatu w zbiorowym spojrzeniu Polaków na kwestie narodowej winy wobec żydowskich pobratymców. Lista głosów w tej materii sukcesywnie się wydłuża, jako jedynie pars pro toto całego dyskursu rozliczeniowego wymienić można więc Złote żniwa: rzecz o tym, co się działo na obrzeżach zagłady Żydów tegoż Grossa we współpracy z Ireną Grudzińską-Gross (Kraków 2011) czy Płuczki. Poszukiwacze żydowskiego złota Pawła Piotra Reszki (Warszawa 2019), last but not least - także cytowaną tu już Prześnioną rewolucję Ledera.
} 
nie stygmatyzuje "duszy polskiej”, pozostawiając ją dziewiczą, co najwyżej obciążoną nostalgiczną tęsknotą ${ }^{13}$.

Otóż Biały kamień powstał jeszcze przed ową znamienną rewolucją paradygmatu, zanim doszło do przesunięcia ciężaru moralnego zagadnienia Zagłady w Polsce, które to przemieszczenie poskutkowało - między innymi - rewolucją poetyki powieściowej, kontrastywnie formującej się w ostatnich latach względem tej obowiązującej w literaturze wcześniejszej (choćby tej „małoojczyźnianej”). Przypominam o tym, by móc w dalszych analizach pomijać współczesny kontekst lektury nieco już zarchaizowanego modelu mitograficznego, „Arkadyjskiego” obrazu „kraju lat dziecinnych”, który powieść przynosi.

Szczupłość miejsca zmusza mnie do szybkich syntetycznych ujęć, więc poetykę powieści potraktuję bardziej hasłowo niż na to, być może, zasługuje.

Utwór Boleckiej wydaje się silnie „zakochany” w niewiele starszej Bohini Tadeusza Konwickiego (1987) ${ }^{14}$ : rama narracyjna ma cechy postpamięciowej rekonstrukcji losów nieznanego narratorce pradziadka ${ }^{15}$; świat przedstawiony bywa na tyle podporządkowany subiektywnej, dziecięcej wyobraźni (spersonalizowanego) narratora, że liryzacja i sensualny opis zdominowują konkret historyczny, w efekcie czego struktura czasowa przypomina mityczne in illo tempore, lokując opowieść $\mathrm{w}$ perspektywie mitów dzieciństwa, małej ojczyzny, raju utraconego; bukoliczność takiej formy jest jednak przełamywana obecnością historii - w porządku ramy narracyjnej Zagłada jest nazwana i opisana bezpośrednio, choć fragmentarycznie, w porządku właściwej opowieści pojawia się poprzez dosłowne zapowiedzi (motyw przedwojennego katolicko-endeckiego antysemityzmu polskiego), ale przede wszystkim przez kilka symbolicznych prefiguracji. Tym samym - podobnie zresztą jak Bohin - Biały kamień w sensie gatunkowym nawiązuje do pierwotnego, Teokrytejskiego, kształtu sielanki, przesyconej nostalgią i melancholią, z nieuchronną obecnością śmierci kadrującej jasny obraz rajskich łąk (motyw et in Arcadia ego).

13 Por. np. P. Czapliński, Literatura małych ojczyzn wobec problemu tożsamości, w: Kultura wobec kręgów tożsamości. Materiały konferencji przedkongresowej, Poznań 19-21 października 2000, red. T. Kostyrko, T. Zgółka, Poznań-Wrocław 2000, s. 24-33; tegoż, Wzniosłe tęsknoty. Nostalgie w prozie lat dziewięćdziesiątych, Kraków 2001.

14 T. Konwicki, Bohiń, Warszawa 1987.

15 Domniemanie bliskiej więzi z Bohinią rodzi się już przy lekturze pierwszych słów powieści: „Nie znałam mojego pradziadka. Urodziłam się czternaście lat po jego śmierci” [A. Bolecka, Biały kamień, Gdańsk 2004, s. 7; dalej cytował będę powieść Boleckiej z tego właśnie, drugiego, wydania]. „Moja babka Helena Konwicka, moja babka, której nigdy w życiu nie widziałem i nie wiem, gdzie i kiedy umarła, moja babka Helena gospodarzyła wtedy, jak się zdaje, z ojcem Michałem w folwarku Bohiń [...]" [T. Konwicki, Bohiń, s. 19]. 
Wobec stosunkowo złożonej, poniekąd szkatułkowej, kompozycji powieściowej narracji, wypada chyba w tym miejscu dokonać szybkiej rekapitulacji zagadnień kompozycyjnych, co, jak się wydaje, ułatwi orientację w dalszej części moich wywodów. Otóż Biały kamień winkrustowany został (winkrustowana została jego właściwa fabuła) w ramę narracyjną opowieści narratorki "pierwszego stopnia” - postaci kobiecej ukształtowanej dramatycznie (w rozumieniu Wayne'a C. Bootha) ${ }^{16}$, fingującej w pierwszych słowach utworu proponowany czytelnikowi pakt autobiograficzny. Fingującej jedynie i to w sposób dość oczywisty, ponieważ przy pozorach konwencjonalnej tożsamości $\mathrm{z}$ autorką powieści narratorka odwołuje się do wysoce dyskusyjnego w świetle zdroworozsądkowej empirii doświadczenia spotkania z duchem pradziadka. Co prawda owo „nawiedzenie” ma miejsce w "genialnej epoce", gdy narratorka ma lat pięć, co pozwala przypisać mu status dziecięcej fantazji, niemniej, dalsza część opowieści osnuta jest wokół jawnie fikcyjnych, rekonstruowanych jedynie w imaginacji - losów owego pradziadka. Można zatem część wstępną fabulacji Boleckiej uznać również za element ramy modalnej, ustanawiającej pewien typ współpracy z czytelniczką/czytelnikiem, odwołujący się - i owszem - w pewnym stopniu do mechanizmów lejeune'owskiego paktu, lecz nie w wymiarze zaufania charakterystycznego dla lektury autobiograficznej, a przeciwnie - temperowanej nieufności związanej z proponowaną, jawnie postpamięciową, rekonstrukcją przeszłości i własnej genealogii. Mamy tu więc do czynienia z pewną strategią dającą się wpisać w model „fikcji jako możliwości" ${ }^{17}$. Jednocześnie, jak się wydaje, pojawiająca się już na wstępie „upiorna” (w romantycznym sensie słowa) obecność Pradziadka jako centralnej postaci fabuły upoważnia do sięgnięcia po narzędzia interpretacyjne $\mathrm{z}$ obszaru widmologii/widmontologii oraz refleksji nad postpamięcią.

Tym, co wspomniana, tyleż narracyjna, ile modalna, rama okala, czyli właściwą materią opowieści Boleckiej, są losy pradziadka narratorki, Franka alias Franciszka alias Pradziadka. Sposób sygnowania bohatera w tekście nie pozostaje bez znaczenia, wobec alternujących perspektyw narracji i fokalizacji przyjmowanych w opowieści. Zderzają się tu więc perspektywy o różnym stopniu prawdopodobieństwa i wiarygodności: punkt widzenia "Gienierała” (wnuka Franciszka i ojca narratorki), samego Franciszka, obu „ukształto-

16 W.C. Booth, Rodzaje narracji, przeł. I. Sieradzki, „Pamiętnik Literacki” 1971, z. 1, s. 231-233.

17 Sam termin zapożyczam, oczywiście, od Anny Łebkowskiej (Fikcja jako możliwość. Z przemian prozy XX wieku, Kraków 1990/Kraków 1998); o możliwościowych ramach modalnych odbioru por. też A. Martuszewska, Powieść i prawdopodobieństwo, Kraków 1992; tejże, Światy (nie)możliwe powieści, Gdańsk 2001. 
wanych dramatycznie" i uformowanych jako medium narracji personalnej ${ }^{18}$, oraz spajające je razem focus i głos (voix, voice) bliżej nieokreślonego, bezosobowego narratora ekstradiegetycznego (tożsamego zapewne z narratorką "ramy") ${ }^{19}$, charakteryzującego się pełnią wiedzy o przedstawionym świecie, jednocześnie jednak dużą dyskrecją, umożliwiającą zamaskowanie granic pomiędzy jego/jej dyskursem narracyjnym a monologami pozostałych, spersonalizowanych mediów.

Porządek kompozycyjny powieści komplikuje się jednak dodatkowo. Następujący bezpośrednio po pierwszoosobowym wprowadzeniu fragment historii przenosi czytelniczkę/czytelnika w lata trzydzieste, okres bezpośrednio poprzedzający wybuch wojny. Postacią ośrodkową i głównym bohaterem jest tu już (jeszcze żyjący, lecz już wiekowy) Pradziadek Franciszek obserwowany tyleż okiem kilkuletniego wnuka, Gienierała, ile własnym spojrzeniem wewnętrznym i fokalizacyjną "kamerą" wspomnianego wcześniej narratora bezosobowego (choć jego konsekwentne posługiwanie się określeniem „Pradziadek" wskazuje na tożsamość z pierwszoosobową narratorką całości). Kolejne wydarzenia, drobne przypadki niczym niewyróżniającego się dnia, stają się stopniowo przesłankami wspomnień, po proustowsku wyłaniających się z pamięci Franciszka i rozwijających w kolejne, odrębne moduły fabularne. Tym samym ów wymyślany, fantazjowany Pradziadek narratorki (pierwszego stopnia), dziadek Gienierała (jednego z narratorów stopnia drugiego) staje się ośrodkowym medium najgłębiej zagnieżdżonej narracji - narracji prowadzonej z perspektywy Franka, Pradziadka-chłopca (narratora trzeciego stopnia). Tym samym domknięta zostaje też konstrukcja („,szkatułkowej” także) struktury czasowej fabuły, a raczej dopełniających się fabuł. Dla mojej interpretacji istotne będzie rozwarstwienie owej struktury czasowej na trzy strumienie: zdarzeń z dzieciństwa Franka (koniec wieku XIX, przełom stuleci), zdarzeń z jego życia dorosłego, przede wszystkim zaś starości i dzieciństwa Gienierała (lata 30. XX wieku, druga wojna światowa), zdarzeń z życia dzieciństwa i okresu dojrzałości - narratorki (II poł. wieku XX). W równym

18 Por. F. Stanzel, Sytuacja narracyjna i epicki czas przeszły, przeł. R. Handke, „Pamiętnik Literacki" 1970, z. 4; tegoż, Typowe formy powieści, przeł. R. Handke, w: Teoria form narracyjnych w niemieckim kręgu językowym, oprac. R. Handke, Kraków 1980. Stanzelowskiego pojęcia „narracji personalnej” używam tu dla skrócenia wywodów „narratologicznych”, które pełnią jedynie rolę pomocniczą $\mathrm{w}$ interpretacji.

19 Tym razem odwołuję się, oczywiście, do kategorii narratologicznych powołanych do życia przez Gérarda Genette'a [por. G. Genette, Discours du récit, w: tegoż, Figures III, Seuil, Paris 1972], a rozwijanych przez Mieke Bal [M. Bal, Narratologia. Wprowadzenie do teorii narracji, przekład zbiorowy pod red. E. Kraskowskiej i E. Rajewskiej, Kraków 2012 (pierwsze wydanie: Toronto 1985)]. 
stopniu jednak za istotne uważam nawarstwienie elementów symbolicznych, rekurujących czy też po prostu powtarzających się w kolejnych epokach zobrazowanych $\mathrm{w}$ powieści. Ich kolejne powroty - w odmianach i wariacjach ustanawiają symboliczną, zatem w pewnym sensie ponadhistoryczną, równoczesność wszystkich owych strumieni czasu. W płaszczyźnie lektury postpamięciowej czy widmontologicznej znoszą one dyskretny charakter poszczególnych biografii i ich indywidualnych rzeczywistości, w porządku historycznym oddzielonych od siebie dekadami. $W$ to miejsce powołują pewną symboliczną jedność osób, społeczności, przypadków i losów, która konstytuuje się poza regnum Czasu, Historii i Śmierci.

Czas wrócić nareszcie do wspomnianych wcześniej symbolicznych prefiguracji Zagłady. Temat żydowski wydaje się w Białym kamieniu nie pełnić roli ośrodkowej. To raczej motyw współkonstytuujący obyczajowo-historyczne tło powieści, choć żydowskie przyjaźnie i fascynacje bohaterów w pewnym sensie otwierają i zamykają narrację, a także dominują w pierwszej połowie utworu. Niemniej tym, co wydaje się (przynajmniej na początku) w utworze najistotniejsze, jest platoński związek głównego bohatera - Franka - z Naturą, z tajemnicami życia i śmierci, erotyzmu, macierzyństwa (jakoś mniej ojcostwa), smaku, zapachu, starzenia się, indywidualnej pamięci, umierania wreszcie... Mamy więc do czynienia z czymś w rodzaju realistyczno-magicznego Bildungsroman. Tajemnice i losy żydów występują w nim na prawach wyróżnionych, ale należących do tego samego uniwersum zagadek, co tajemnice i losy Ukraińców, Białorusinów, a także zwierząt - ich życia, cierpienia, śmierci. Niemniej - jeżeli przywołać Freudowskie analizy pracy marzenia sennego i rolę przemieszczenia lub Lacanowsko-Žižkowską koncepcję anamorfozy i "spojrzenia z ukosa” - z pozoru mało istotne wzmianki, epizodyczne motywy, "ślepe uliczki" narracji dają do myślenia. Prorocze sny Rojzy, matki Benka, samego Benka, wreszcie jego córki z pewnością odsyłają do wyobrażeń ofiary całopalnej, spopielenia, unicestwienia. Wymiar eschatologicznej zapowiedzi mają zarówno opis Jom Kippur we wsi i towarzyszącej mu gry na rogach Szofar, jak i wizyta Franka na kirkucie. Są w powieści jednak i inne - bardziej niepokojące znaki żydowskości (lub relacji goj-żydzi) postrzeganej jako główny problem i największa tajemnica. Co niezmiernie ciekawe - na ogół pojawiają się one w porządku fantazji erotycznych któregoś z wiodących bohaterów - bądź Franka, bądź jego wnuka, Gienierała, ojca narratorki. Jeżeli motyw chłopięcej przyjaźni goja i żyda pojawia się jedynie w kontekście biografii Pradziadka Franka, o tyle wątek fascynacji sentymentalnych splatających losy goja i żydówki ma charakter struktury paralelnej, ustanawiającej ponadczasową analogię między Franciszkiem a jego wnukiem. I przy wszelkich pozorach idylliczności 
materią pożądania rządzi $\mathrm{w}$ tej powieści bóstwo o janusowych obliczach Erosa i Freuda.

Mały Franek formowany jest przez świat przedoświeceniowy - obok religijnej (ludowo katolickiej) rytualności „od święta”, codzienność chłopów podporządkowana jest rozmaitym przesądom, tworzącym całe uniwersum praktyk i znaczeń, nakazów, zakazów, wyobrażeń. Zanim stanie się młodym Franciszkiem, wybranym przez starców, by z - równie arbitralnie wskazaną - Podolanką rytualnie "taczać się" w polu, i wespół zapładniać rolę młodą mocą, na co dzień wiedzie życie pośród stworzeń zamieszkujących pogranicza światów, tworów, co do których nie wiadomo, na ile przynależą realnej wiejskiej nędzy, na ile transcendencji i jakiemuś nieznanemu sacrum, a na ile pospólnym lub własnym wyobrażeniom wiejskiej dzieciarni. Po podwórcach zagród grasuje więc krwiożerczo-zabawne Kurze Płucko, a niedorozwinięty pastuch-płanetnik, Skikałko, włada deszczem i karmi zaprzyjaźnione węże, przystawiając je do krowich wymion ${ }^{20}$. Pośród „strachów”, od których roi się dziecięco-chłopski świat Franka, najważniejszy jest „wyk” - zaświatowy pająk-śmierć, mieszkający pod stropową belką - i kobiece widmo, swoiste ucieleśnienie Matki Natury, Persefony, Marzanny darzącej życiem i śmiercią. W odróżnieniu od chłopów, pośród których żyje, Franek nie lęka się jej, uwielbia podglądać ją biegnącą po mokrych od rosy łąkach, w dodatku dość wyraźnie ucieleśnia ona jego fantazje matczyno-erotyczne. To widmo-bóstwo ma na imię Chawa, przy całym swoim słowiańsko-indoeuropejskim nacechowaniu, nosi wyraźnie żydowskie miano (odpowiednik Ewy, pramatki). Na erotyzm tego wyobrażenia życia-śmierci wskazuje narracja expressis verbis, mówiąca o nagich, dorodnych piersiach bóstwa, które przyciągają uwagę Franka. Mniej narzuca się łatwy do przeoczenia fakt, że Chawa jest poniekąd prefiguracją przedśmiertnej wizji starego Franciszka (wiele laty później), w której dokonuje się jego symboliczny powrót do matki, nie tyle może do jej łona, ile właśnie do matczynej piersi odpomnianej w nagłym śnie-fantazji-zwidzeniu. Czytamy więc najpierw:

Chawa przeskakiwała wodne oczka, unosiła się nad wysokimi trawami. [...] Miała rozdartą koszulę i piersi ciężko zwisające po bokach. Musiał być to powidok jakiegoś zdarzenia z jego wczesnego, pozornie całkiem zapomnianego

${ }^{20}$ Na marginesie tych rozważań może warto podkreślić, że płanetnicy, dziwaki, dla których Bóg zapomniał stworzyć dziewczyny, uchodzą pośród niektórych za istoty dzieworódcze (a więc swoiście gynoandryczne), a Skikałko obrazowany jest w okolicznościach wskazujących na jego pokrewieństwo z sacrum płodności. Chodzi tu i o jego zdolność władania chmurami deszczowymi, i o „przemianę” krowy w byka (gdy do wymienia przystawia węża), i o spontaniczny udział w rytuale "taczania”, gdy falliczno-chtonicznego węża ciska na nagie uda Podolanki. Por. A. Bolecka, Biały kamień, s. 48-52, 100-101. 
dzieciństwa. Obraz widzianych kiedyś piersi nałożył się na postać wyobrażonego straszydła [Bk, s. 35-36].

W jednej z finalnych scen powieści Pradziadek powraca zaś wspomnieniem do zasugerowanej wyżej kleinowsko-kristevowskiej „,sceny pierwotnej”:

zapadł w sen, który trwał minuty, a może sekundy. [...] Leżał zawieszony w przestrzeni, opuszczony i pełen śmiertelnego strachu. Nagle, tuż nad nim pojawiła się twarz kobiety i jednocześnie lunął ciepły rzęsisty deszcz. [...] Kobieta rozpięła bluzkę i przytuliła go do do swojej mlecznej piersi. [...] Słyszał przytłumione dźwięki, mruczenie, głośny oddech i śpiew: „Na Podolu biały kamień, na Podolu..." [Bk, s. 174] $]^{21}$.

Wyprzedzając nieco dalszy tok rozważań, warto przy tej okazji wskazać, że przytoczona anamnesis sprowadza z zaświatów nieświadomego nie tylko obraz matki, ale również imię (metonimicznie, wszak „Podolanka” jest antonomazją) tej, której kobieca moc spętać go miała na życie. Pieśń tu cytowana okazuje się jedną z najważniejszych przesłanek oczarowania Pradziadka wdziękiem Podolanki:

Kobiety i dziewczęta, zmęczone dniem, kładły się nad wodą. Wyprane płótna, rozciągnięte na trawie, dosychały $w$ promieniach zachodzącego słońca. Pachniało świeżością, wodą i wiatrem, a głos śpiewaczki niósł się daleko po stokach. „Na Podolu biały kamień, na Podolu biały kamień. Podolanka siedzi na nim, Podolanka siedzi na nim".

Wychylał się ostrożnie zza gęstej wikliny i przez szpary między gałązkami patrzał na siedzącą tyłem dziewczynę. W jej długie rudawe włosy wplątały się źdźbła zeschłej trawy i łodyżki ziół [Bk, s. 95].

W powyższym wyimku uderza również wzmianka o rudawo-blond kolorze włosów ukochanej Franciszka. Motyw włosów tej barwy - na mocy kulturowego stereotypu - w kilku miejscach powieści dyskretnie, ale konsekwentnie (szczególnie, gdy zestawić go z paralelnie z nim występującymi metonimiami żydowskości) sugeruje tajemnice (zapomnianej, utraconej, wypartej) żydowskiej genealogii kobiet, bohaterek Białego kamienia.

\footnotetext{
${ }^{21}$ Na marginesie - aby silniej uzasadnić tezę o przemyślanej, zasadzającej się na paralelizmach symbolicznych, konstrukcji utworu - można tu przypomnieć, że przywołana scena jest w utworze prefigurowana bardzo podobną, rozgrywającą się w epoce wczesnej dojrzałości męskiej Franciszka. Oto jego młoda, niekochana żona, Genowefa, karmi piersią i składa na ziemi ich syna, ojca Gienierała (a zatem dziadka narratorki). Ten macierzyńsko-magiczny rytuał rozgrywa się w nieobecności Pradziadka Franciszka. Zresztą zaprzątnięty „przedustawną” miłością do Podolanki prawie całkowicie ignoruje on w tamtym momencie tajemnice macierzyństwa prababki Genowefy i własnego ojcostwa. Por. A. Bolecka, Biały kamień, s. 110-112.
} 
Zanim ruda Podolanka, dziewczyna (później kobieta), najpierw fantazmatycznie, później całkowicie realnie, bierze w niewolę wyobraźnię, serce, pożądanie Franka, objawia się jego Erosowi już w "genialnej epoce" wczesnego dzieciństwa. W jednym $\mathrm{z}$ najstarszych jego wspomnień, przedstawiającym kąpiącą się dziewczynkę, Franek straszy ją starym rasistowsko-seksistowskim żartem: „A ty masz taką kreskę i jak będziesz duża, to ci się przekręci [...]. Pokaż! - rozkazał po chwili" [Bk, s. 17]. Sugestia żydowskiego pochodzenia Podolanki nigdzie oprócz tego miejsca nie pada. Podobnie jak sugestia żydowskiego pochodzenia samego Franka. Niemniej - ona, wychowana jako Ukrainka, on - jako polski chłop, są podrzutkami, dziećmi niejasnej genealogii, co samo w sobie konstytuuje pewien przemilczany, „kryptyczny" (w rozumieniu Abrahama, Törok, Nicholasa Randa) wątek Białego kamienia. Szczegółowe nad nim rozważania odkładam na inną okazję, tu skupiając się na żydowskim wymiarze fantazmatyki Erosa i Thanatosa.

Tlenione na blond włosy to także emblematyczny znak Julci Słowik, obdarzonej talentem śpiewaczym dziewczyny, w obecności której zaczynają się rozbudzać erotyczne niepokoje Frankowego wnuka - „Gienierała”. Nieśmiała, nigdy nie mająca się spełnić w dorosłym życiu, dziecięca fascynacja Gienierała Julcią, to motyw kontrapunktujący romans Franciszka i Podolanki. Kiedy matka chłopca, Anisja, z przekąsem zwraca uwagę na fakt, że nastoletnia Julcia rozjaśnia włosy, by "złagodzić" żydowski wymiar swej urody, Gienierał wycina na poręczy schodów łączących ich mieszkania napis "utleniona”. Jest rok 1938, do śmierci Julci w lubelskim getcie pozostają jeszcze cztery lata. Napis ten - jedną z niewielu materialnych pozostałości historii - odnajdzie w roku 1988 narratorka: jego odkrycie domyka główną kompozycyjną ramę powieści. W nim właśnie widzę jeden z anamorficznych znaków wagi problematyki Zagłady - „widziane z ukosa” utlenienie w języku chemii wskazuje na (gwałtowny - to już raczej konotacja) proces spalania ${ }^{22}$. „Utleniona” Julcia - znak pożądań młodziutkiego Gienierała, jest równocześnie drastyczną prefiguracją spopielenia jej dziecięco-erotycznego ciała, pośrednio oczywiście - całego narodu. Jest to fantazmat gwałtowniejszy może w swojej sile niż metafora zaniknięcia wraz z Zagładą „słowiczego" głosu Julci, rozkochanej w Mozarcie i niemczyźnie jego librett.

22 Posiłkuję się tu, naturalnie, opisywaną przez Slavoja Žižka metodą interpretacji anamorficznej „plamy” (elementu zbędnego w obrazie, zakłócającego jego zdroworozsądkową harmonię, i z pozoru nieprzedstawiającego, pozbawionego referencji). Por. S. Žižek, Patrząc z ukosa, w: tegoż, Patrząc z ukosa. Wprowadzenie do Jacques'a Lacana przez kulturę popularnq, przeł. J. Margański, Warszawa 2003. 
"Utlenienie" jako fantazmat pożądania i (transpasywnej) agresji to jeden z dwóch kluczowych punktów wyjściowych mojej interpretacji. Drugim jest najbardziej abjectualna scena powieści - „wskrzeszenia” chorego przyjaciela Pradziadka, Benka, z parujących trzewi wieprza. Jest to scena naznaczona „złym sumieniem” voyeuryzmu - Franek podgląda magiczne procedery odprawiane przez "Rosochatego", ukraińskiego znachora, do którego zabierają Benka Rojza, matka, i babka - Klajne Bobe. Wskrzeszenie młodego żyda ma przy tym charakter drastycznej transgresji religijnej kontakt dziecka ze świeżym, krwawiącym truchłem wieprza narusza Kosher $\mathrm{w}$ takim stopniu, że budzi żywiołowy, agresywny protest babki. Nad Prawem (religijnym, ojcowskim, symbolicznym) odnosi jednak zwycięstwo prawo matki (cielesne, przedrefleksyjne, afektywne). To matka, mimo żywiołowych protestów babki, z pełną rozpaczy determinacją nalega, by umierającego chłopca ocalić, nie zważając na bluźnierczy charakter leczniczo-magicznych zabiegów.

Oto, co widzi Franek. Umierający Benek zostaje zawiązany niczym płód $\mathrm{w}$ parujących jeszcze trzewiach świeżo zaszlachtowanego wieprza. Nogi zwierzęcia zostają związane. Wkrótce chłopiec zostaje ze świńskiego ciała wydobyty niczym nowo narodzony, a z wszelkich otworów jego ciała wychodzą robaki. "Majesz syna” - zwraca się do Rojzy Rosochaty słowami rytualnie przynależnymi chwili porodu [por. Bk, s. 76-80].

Scena ta umieszczona w porządku rozważań Julii Kristevej nad wstrętem ujawnia związki abjectualnego obrzydzenia z seksualnością, przede wszystkim z cielesnym wymiarem macierzyństwa i procesem oddzielenia dziecięcego ciała od ciała matki, co wiąże się z wejściem w porządek symboliczny (Imię Ojca - w tym przykładzie $w$ roli figury ojcowskiej występuje znachor) i indywiduacją (w sensie ukształtowania dziecka jako podmiotu odrębnego od macierzyńskiej cielesności) ${ }^{23}$. Rozświetla też związki tego, co budzące wstręt, z traumatycznym doświadczeniem tych przestrzeni realnego (w sensie lacanowskim), które odsyłają do wypartego / zatartego wspomnienia cielesności matczynej.

Jeżeli wy-miot/abject, wobec którego postawieni, stajemy twarzą w twarz, a raczej "trzewiami w trzewia" /,rzygami w rzygi”, ze wstrętem, odrazą tak gwałtowną, że ukierunkowującą nas momentalnie ku afektywnemu odczuciu zagrożenia naszej spoistości podmiotowej, jeżeli - jak właśnie twierdzi Kristeva - jest on równoznaczny ze spontanicznym wynurzeniem się z nieświadomości refleksu pierwotnej naszej wspólnoty z ciałem matki,

23 Por. J. Kristeva, Potęga obrzydzenia. Esej o wstręcie, przeł. M. Falicki, Kraków 2008, szczególnie fragmenty Przed początkiem: oddzielenie, s. 17-18 oraz Zetknięcie z tym, co matczyne, s. 55-56. 
wspólnoty groźnej, bo właśnie niezostawiającej miejsca na nasze indywidualne istnienie, upodmiotowienie, wówczas nasuwa się pytanie o symboliczny wymiar tej właśnie sceny w porządku powieściowym.

Ze względu na ograniczoną ilość miejsca dokonam teraz szybkich interpretacyjnych przeskoków, tworząc swoisty ciąg równań symbolicznych, cofając się od obrazu do jego - przeczuwanych przeze mnie - źródeł.

(1) Abjectualna „scena pierwotna”: trup, krew, robaki, nieczystość rytualna wieprza i porodu, narodziny żyda.

Prócz obrzydzenia (podyktowanego obcowaniem z po-miotem) równie ważny jest w niej aspekt transgresji "ojcowskiego" Prawa: zarówno wieprz, jak i robaki są rytualnie nieczyste w świetle Ksiag Kapłańskiej, Liczb i Powtórzonego prawa, stanowią więc widomy znak transgresji Zakonu, a obraz - jako wymykający się racjonalizacji, i fantasmagoryczny - lokuje się również w przestrzeni poza czy też „przed” dyskursem, odsyłając do lacanowskiego porządku realnego, przedsymbolicznego, poprzedzającego uformowanie podmiotu i wciąż pozostającego poza władzą Prawa i Imienia Ojca.

(2) Budzący wstręt świński trup i symboliczna ekwiwalencja względem szeregu skojarzeń: ciało matki, ciało (mojej) żydowskiej matki.

Abjectualne truchło jest oczywiście łonem matczynym w świetle Kristevowskiej koncepcji po-miotu (Inter feces et urinam nascimus). Łonem żydowskim jest zaś na mocy metonimii (skoro wy-łania się zeń Benek Lubin). Łonem mojej (Franka) matki-żydówki z kolei - za sprawą fantazmatu ugruntowanego w kryptycznej, okrytej milczeniem, lecz sygnalizowanej w powieści rozmaitymi drobiazgami (žižkowskimi „plamami”, abrahamowskimi „uskokami" mowy) tajemnicy genealogicznej. Jeśli Franek nawet nie jest dzieckiem żydowskim, domniemanie takie zdecydowanie czai się gdzieś na granicy jego świadomości i kołacze do niej nieustannie. Na ten wariant rozwiązania zagadki jego pochodzenia, rodowodu dziecka poczuwającego się do katolicyzmu, lecz przecież niewiadomej krwi (a także zagadki pochodzenia Podolanki) wyznaczają między innymi jego i jego wnuka Gienierała dziecięce fantazje erotyczno-thanatyczne ogniskujące się wokół symbolicznych i dyskursywnych indeksów żydowskości kobiecej (rude/utlenione włosy, demoniczne łono „w poprzek”, imię Chawy, przy czym rudy kolor włosów ma charakter przeoczonej „plamy”, wzmianka o "kresce”, która „się przekręci” to z kolei przykład mowy "uskokowej" ${ }^{24}$ ).

24 Por. następujący fragment: „Rozwiązaniem dla podmiotu kryptoforycznego [id est rozszczepionego skutkiem istnienia w jego nieświadomym obcej inkluzji - „krypty” wstydu dziedziczonego międzypokoleniowo, często związanego z nieprawym pochodzeniem - M.D.] staje się zniesienie upokorzenia poprzez skryte lub jawne zaadoptowanie dosłownego znaczenia 
W dalszym ciągu wypada teraz wskazać na permanentnie powtarzające się $\mathrm{w}$ powieści elementy fantazmatyki agresji w wyobraźni erotycznej młodych bohaterów (obu pokoleń): włosy utlenione/spalone, Chawa-śmierć i miłość (miłość matczyna/pragnienie) ${ }^{25}$. Zestawione z wyżej wyszczególnionym szeregiem skojarzeń ujawniają charakter dramatu głęboko ukrytego pod werniksami bukoliczno-nostalgicznej panoramy arkadyjskich Kuromęk.

(3) Żydówka - zarazem matka i kochanka - jest więc w powieści obciążona ambiwalentną symboliką pożądania i lęku/agresji, charakterystyczną dla opisywanej przez Kristevą relacji przededypalnej dziecka i ciała matki:

to, co wstrętne [...] - pisze autorka Czarnego słońca - w naszej osobistej archeologii, konfrontuje nas z najdawniejszymi próbami odgraniczenia się od matczynej istoty, zanim nawet zaczniemy egzystować poza nią dzięki autonomii języka. Odgraniczeni gwałtowne i niezręczne, nieustannie zagrożone przez ponowne popadnięcie $\mathrm{w}$ zależność od mocy zarazem dającej bezpieczeństwo i przytłaczającej. [...] Wstręt, w szerszym sensie podmiotowej diachronii, to warunek przedwstępny narcyzmu ${ }^{26}$.

(4) Postaci Franka i jego podwojenia/sobowtóra, Gienierała interpretować możemy w świetle wcześniejszych rozważań jako ucieleśniających pars pro toto relację "polski goj i (jego) żydowskość”; tożsamość żydowska funkcjonuje tu bowiem także jako kryptyczna/wyparta tajemnica genealogii.

(5) Katolik pożąda i lęka się swej żydowskości (czyż nie o tym świadczy figura żydowskiej matki?). Żydowskość jest symbolicznie zrównana z macierzyństwem, a tym samym obciążona abjectualnie. „Indywiduacja” katolika - w wymiarze jednostkowym figurą jest tu Gienierał, ale symbolika ta synekdochicznie dotyczy etosu polsko-katolickiego jako takiego - podmiotowe zaistnienie Polaka-katolika wymaga odłączenia się od ciała żydowskiej matki, zdobycia sobie życiowej przestrzeni w oderwaniu od niej.

słów niosących owo upokorzenie" [N. Abraham, M. Torok, Mourning or Melancholia: Introjection vs. Incorporation, w: tychże, The Shell and the Kernell. Renevals of Psychoanalysis, vol. 1, ed. N.T. Rand, Chicago-London 1994, s. 131]. W omawianym przypadku owym słowem ujawniającym w swej dosłowności kryptyczny charakter rodowodu Franka jest „,̇̇ydowska” "kreska w poprzek"; ta, która ową kryptę zamieszkuje, to oczywiście rudowłosa Chawa o obfitych mlecznych piersiach, figura matki-żydówki.

25 Por. nast. cytat: „Nie bał się Chawy [...]. Stała po stronie mroku, ale była zarazem symbolem życia i jego tajemnicy. [...] Była przecież obrazem śmierci, umrzykiem wcielonym w postać pięknej dziewczyny" [Bk, s. 36].

${ }^{26}$ J. Kristeva, Potega obrzydzenia. Esej o wstręcie, s. 18. 
Innymi słowy - formowaniu się współczesnego wariantu narodowości polskiej (zmonopolizowanej przez indeksalnie potraktowaną katolickość) towarzyszy afekt za Lacanem nazywany przez Andrzeja Ledera transpasywnością (czerpania ukrytej rozkoszy z dokonanego cudzymi rękami zgładzenia żydowskiej matki) ${ }^{27}$.

(6) Przestrzenią abjectu - do której odwołuje się tytuł moich rozważań - jest tu w porządku figuracji budzące wstręt ciało wieprza - żydowskość, z której fantazmatycznie rodzę się ja sam (bohater, spersonalizowany narrator, Franek, czytelnik, ja-Maciek). W porządku metafory natomiast jest nią przestrzeń - Lebensraum - którą uzyskaliśmy w uniwersum społeczno-ekonomicznym po Holokauście za sprawą transpasywnie przeżytej Zagłady. Przestrzeń owa również nosi znamiona abjectu - świadectwa Całopalenia (Auschwitz, Jedwabne, Kielce, Kraków) budzą wstręt i (jako wy-miot) wymykają się racjonalizującemu dyskursowi, zagrażają naszej podmiotowej integralności, przypominając o nierozdzielnym niegdyś związku nas samych (etnicznie nasyconych wypieraną żydowskością, a symbolicznie będących żydowskimi dziećmi pary archetypowych Żydów Jezusa i Maryi) z gwałtownie „utlenionym" ciałem żydowskiej matki. Mojej żydowskiej matki.

\section{Bibliografia}

Abraham Nicholas, Torok Maria (1994), Mourning or Melancholia: Introjection vs. Incorporation, w: N. Abraham, M. Torok, The Shell and the Kernell. Renevals of Psychoanalysis, vol. 1, ed. N.T. Rand, Chicago-London: University of Chicago Press, s. $125-136$.

Bal Mieke (2012), Narratologia. Wprowadzenie do teorii narracji, przekład zbiorowy pod red. E. Kraskowskiej i E. Rajewskiej, Kraków: Wydawnictwo Uniwersytetu Jagiellońskiego.

Bikont Anna (2004), My z Jedwabnego, Warszawa: Prószyński i Spółka.

Bikont Anna (2012), My z Jedwabnego, Warszawa: Wydawnictwo Czarne.

Bolecka Anna (2004), Biały kamień, Gdańsk: Słowo/Obraz Terytoria.

Booth Wayne C., Rodzaje narracji, przeł. I. Sieradzki, „Pamiętnik Literacki” 1971, z. 1, s. 229-244.

Czapliński Przemysław (2000), Literatura małych ojczyzn wobec problemu tożsamości, w: Kultura wobec kręgów tożsamości. Materiaty konferencji przedkongresowej, Poznań 19-21 października 2000, red. T. Kostyrko, T. Zgółka, Poznań-Wrocław: Wydawnictwo DTSK Silesia.

27 Por. A. Leder, Prześniona rewolucja. Ćwiczenia z logiki historycznej, s. 21. 
Czapliński Przemysław (2001), Wzniosłe tęsknoty. Nostalgie w prozie lat dziewięćdziesiątych, Kraków: Wydawnictwo Literackie.

Didi-Huberman Georges (2008), Obrazy mimo wszystko, przeł. M. Kubiak Ho-Chi, Kraków: Universitas.

Genette Gérard (1972), Discours du récit, w: G. Genette, Figures III, Paris: Seuil.

Gross Jan Tomasz (2000), Sąsiedzi. Historia zagłady żydowskiego miasteczka, Sejny: Pogranicze.

Gross Jan Tomasz, Grudzińska-Gross Irena (2011), Złote żniwa: rzecz o tym, co się działo na obrzeżach zagłady Żydów, Kraków: Znak.

Jennings Lee Byron (1979), Termin „groteska”, przeł. M.B. Fedewicz, „Pamiętnik Literacki", z. 4, s. 281-318.

Konwicki Tadeusz (1987), Bohiń, Warszawa: Czytelnik.

Kostyrko Teresa, Zgółka Tadeusz [red.] (2000), Kultura wobec kręgów tożsamości. Materiały konferencji przedkongresowej, Poznań 19-21 października 2000, Poznań-Wrocław: Wydawnictwo DTSK Silesia.

Kristeva Julia (2008), Potęga obrzydzenia. Esej o wstręcie, przeł. M. Falicki, Kraków: Wydawnictwo Uniwersytetu Jagiellońskiego.

Leder Andrzej (2014), Prześniona rewolucja. Ćwiczenia z logiki historycznej, Warszawa: Wydawnictwo Krytyki Politycznej.

Łebkowska Anna (1991), Fikcja jako możliwość. Z przemian prozy XX wieku, Kraków: Universitas.

Martuszewska Anna (1992), Powieść i prawdopodobieństwo, Kraków: Universitas.

Martuszewska Anna (2001), Światy (nie)możliwe powieści, Gdańsk: Wydawnictwo Uniwersytetu Gdańskiego.

Nycz Ryszard (2014), Afektywne manifesty, „Teksty Drugie”, nr 1, s. 9-13.

Ostachowicz Igor (2012), Noc żywych Żydów, Warszawa: Wydawnictwo W.A.B.

Pawłowska-Jądrzyk Brygida (2002), Sens $i$ chaos w grotesce literackiej. Od "Pałuby" do „Kosmosu”, Kraków: Universitas.

Pawłowska-Jądrzyk Brygida (2017), Ciężar i lekkość w kulturze. Poetyka, estetyka, style myślenia, Warszawa: Wydawnictwo Naukowe Uniwersytetu Kardynała Stefana Wyszyńskiego.

Quignard Pascal (2002), Seks i trwoga, przeł. K. Rutkowski, Warszawa: Czytelnik.

Reszka Paweł Piotr (2019), Płuczki. Poszukiwacze żydowskiego złota, Warszawa: Wydawnictwo Agora.

Słobodzianek Tadeusz (2009), Nasza klasa, Gdańsk: Słowo/Obraz Terytoria.

Stanzel Franz (1970), Sytuacja narracyjna i epicki czas przeszły, przeł. R. Handke, „Pamiętnik Literacki", z. 4, s. 219-232.

Stanzel Franz (1980), Typowe formy powieści, przeł. R. Handke, w: Teoria form narracyjnych w niemieckim kręgu językowym, oprac. R. Handke, Kraków: Wydawnictwo Literackie, s. 237-287.

Žižek Slavoj (2003), Patrząc z ukosa. Wprowadzenie do Jacques'a Lacana przez kulturę popularna, przeł. J. Margański, Warszawa: Wydawnictwo KR. 


\title{
Lebensraum and the Space of Abject Art: On Biały kamień by Anna Bolecka
}

\begin{abstract}
The article analyzes the category of literary space which is understood here rather as a metaphor of experiencing identity, memory and postmemory than as a spatial term sensu stricto. The author reflects on the novel by Anna Bolecka, Biaty kamień [White stone], and more specifically on the hidden tropes of the blurred and denied past memories of Jewish genealogical component of today's Polishness. The reading of the novel's poetics demonstrates the importance of female characters that, apart from their function in the plot construction, figuratively signify the lost Jewish mother of today's, mostly Catholic, Poland. In addition, following the thinking of Julia Kristeva, of special significance are the images of abject art.

Keywords: identity, post-memory, literary space, space as a metaphor, Polish-Jewish relations
\end{abstract}

